\section{The first report of the widow spider Latrodectus elegans (Araneae: Theridiidae) from India}

A. Kananbala ${ }^{1}$, K. Manoj ${ }^{2}$, M. Bhubaneshwari ${ }^{3}$, A. Binarani ${ }^{4} \&$ Manju Siliwal ${ }^{5}$

1,2.3.4 Entomology Research Laboratory, P.G. Block, Department of Zoology, D.M. College of Science Imphal, Manipur 795001, India

${ }^{5}$ Wildlife Information Liaison Development Society, 96, Kumudham Nagar, Vilankurichi Road, Coimbatore, Tamil Nadu 641035, India

Email: ${ }^{1}$ akhamkanan@gmail.com, ${ }^{2}$ naitu_konthou@yahoo.com ${ }^{3}$ mbhubaneshwari@yahoo.com, ${ }^{4}$ bina3athokpam@gmail.com,

${ }^{5}$ manju@zooreach.org (corresponding author)

The comb-footed spider family Theridiidae is popular for the widow spider genus Latrodectus Walckenaer, 1805, which has clinical significance (Daniel \& Soman 1961; Siliwal \& Kumar 2001; Kumar \& Siliwal 2005). So far, 31 species of Latrodectus have been reported from the world (Platnick 2012). Of these, three species L. erythromelas Schmidt \& Klaas 1991, L. geometricus CL. Koch, 1841 and L. hasselti Thorell, 1870 have been reported from India (Siliwal \& Kumar 2001; Kumar \& Siliwal 2005; Shukla \& Broome 2007; Javed et al. 2010). L. hasselti is reported from Gujarat, Maharashtra and Tamil Nadu (Simon 1897; Pocock 1900; Daniel \& Soman 1961; Kumar \& Siliwal 2005; Shukla \& Broome 2007), whereas L.

Date of publication (online): 26 July 2012

Date of publication (print): 26 July 2012

ISSN 0974-7907 (online) | 0974-7893 (print)

Editor: Barbara Knoflach-Thaler

Manuscript details:

Ms \# 03152

Received 09 April 2012

Final received 28 May 2012

Finally accepted 04 July 2012

Citation: Kananbala, A., K. Manoj, M. Bhubaneshwari, A. Binarani \& M. Siliwal (2012). The first report of the widow spider Latrodectus elegans (Araneae: Theridiidae) from India. Journal of Threatened Taxa 4(7): $2718-2722$

Copyright: $\odot$ A. Kananbala, K. Manoj, M. Bhubaneshwari, A. Binarani \& Manju Siliwal 2012. Creative Commons Attribution 3.0 Unported License. JoTT allows unrestricted use of this article in any medium for non-profit purposes, reproduction and distribution by providing adequate credit to the authors and the source of publication.

Acknowledgements: AK would like to thanks UGC grant No. MRPF. No.-39-589/2010(SR) for financial support, during which the spider was found.

OPEN ACCESS | FREE DOWNLOAD geometricus was recently reported from Pune (Shukla \& Broome 2007) and L. erythromelas from

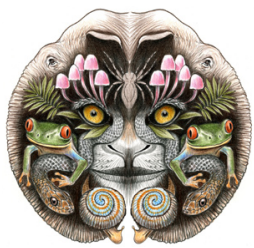
Andhra Pradesh (Javed et al.

2010). While carrying out spider surveys in Manipur, we collected three female specimens of Latrodectus sp. On scanning the literature, it was found that morphologically the specimens from Manipur resembled Latrodectus elegans Thorell, 1898. Further, the species was confirmed by examining the epigynum structure of the female under a stereomicroscope. Prior to this report, L. elegans was reported from China, Myanmar and Japan.

The type locality of L. elegans is Carin Cheba mountains in Burma (=Myanmar). Geographically, Manipur shares a border with Myanmar, therefore, many Indo-Malayan species have been reported from northeastern India especially states which border with Myanmar (Hora 1944; Koopman 1989; Corbet \& Hill 1992; Choudhury 2001; Slowinski et al. 2001; Datta et al. 2003; Athreya 2006; Devi \& Yadava 2006; Ningombam \& Bordoloi 2007; Mahony \& Zug 2008). In the past, there have been no proper surveys for spiders carried out in Manipur and nearby states, therefore, this species remained unreported. Here, we report the occurrence of L. elegans from Manipur, which is a first record for India. We provide a description of $L$. elegans along with natural history notes based on fresh specimens collected from Manipur.

Methods: The specimens were studied in the Entomology Research Laboratory, P.G. Block of Zoology Department, Dhanamanjuri College of Science, Imphal. Photographs were taken after anaesthetizing the spider with carbon tetrachloride. Morphometry of the spider was taken with vernier caliper and ocular meter. All measurements are in $\mathrm{mm}$. One specimen of Latrodectus elegans is deposited in the Zoology Department P.G. Block, Dhanamanjuri College of Science, Imphal, Manipur and another two specimens are deposited at the Wildlife Information Liasion Development Society, Coimbatore. All measurements are in $\mathrm{mm}$. 


\section{Latrodectus elegans Thorell, 1898}

(Figs. 1-5; Image 1-5)

Material Examined: Two females, 5-8.v.2011, elevation 930m, (24055'08.85”N \& 94009'13.59”'E), Thawai Village, Ukhrul District, Manipur, India, coll. K. Manoj, A. Kananbala \& M. Bhubaneshwari (WILD, WILD-11-ARA-1113, WILD-11-ARA-1114).

Description of female (WILD-11-ARA-1113): Total length 9.53. Cephalothorax 5.8 long, 5.73 wide. Abdomen 3.73 long, 3.36 wide and 6.01 high. Morphometry of legs and palp given in Table 1. Leg formula 1423.

Colour in life (Images. 1-3): Carapace, abdomen, spinnerets and legs black. Metatarsi and tarsi of all legs slightly lighter than the rest of the legs. Abdomen black with bright blood-red pattern on dorsum, posterior half chevron shape extending laterally and on anterior half two curved bands (Image 1); ventrally an hour-glass mark, blood red between epigastric area and spinnerets (Image 3); a vertical black-line in the middle of the hour-glass mark. Book lung light brown, epigynum reddish-brown. The book lungs, epigynum, epigastric furrow are surrounded by a light yellowish border, the extension of the red hour-glass. In alcohol, red colour pattern on abdomen fades and is yellowish- red dorsally but large patch on ventral side disappeared reducing to a yellowish-cream patch of lower lip shape below the epigastric furrow and an irregular patch above the spinnerets, in between connecting red patch is not visible, but it is replaced with blackish colour as the rest of the abdomen.

Carapace (Fig. 1; Images 1,3): black, fovea as wide depression in the centre, striae radiating on sides. Slightly longer than wide, thoracic area broader than cephalic area, ocular area high gradually sloping posteriorly. Spines absent, covered with small hairs. Eyes (Fig. 1): eight, transparent eyes except PME, opaque, on low tubercles, two rows anterior row recurved, posterior rows slightly recurved; PME distinctly large, PLE, ALE subequal and AME-PME equal. Diameter of PME=AME, 0.20, PLE=ALE, 0.3; Distance between AME-AME, 0.20, PME-PME, 0.27, PME-PLE 0.27, AME-ALE, 1.30, ALE-PLE, 0.33; MOQ, square, 0.67 wide, 0.73 long; Ocular group 1.00 long and 1.87 wide. Clypeus: yellowish, glabrous with long posterior end as seen in the genus steotoda. Chelicerae: 1.27 long, 0.47 wide, yellowish-orange with light brown fangs, two black dots at base on either side of fangs. Labium (Fig. 2): wider (1.00) than long (0.73), yellowish with 8-9 black hairs. Maxillae (Fig. 2): 1.0 long anteriorly, 1.47 long posteriorly, 0.6 wide,
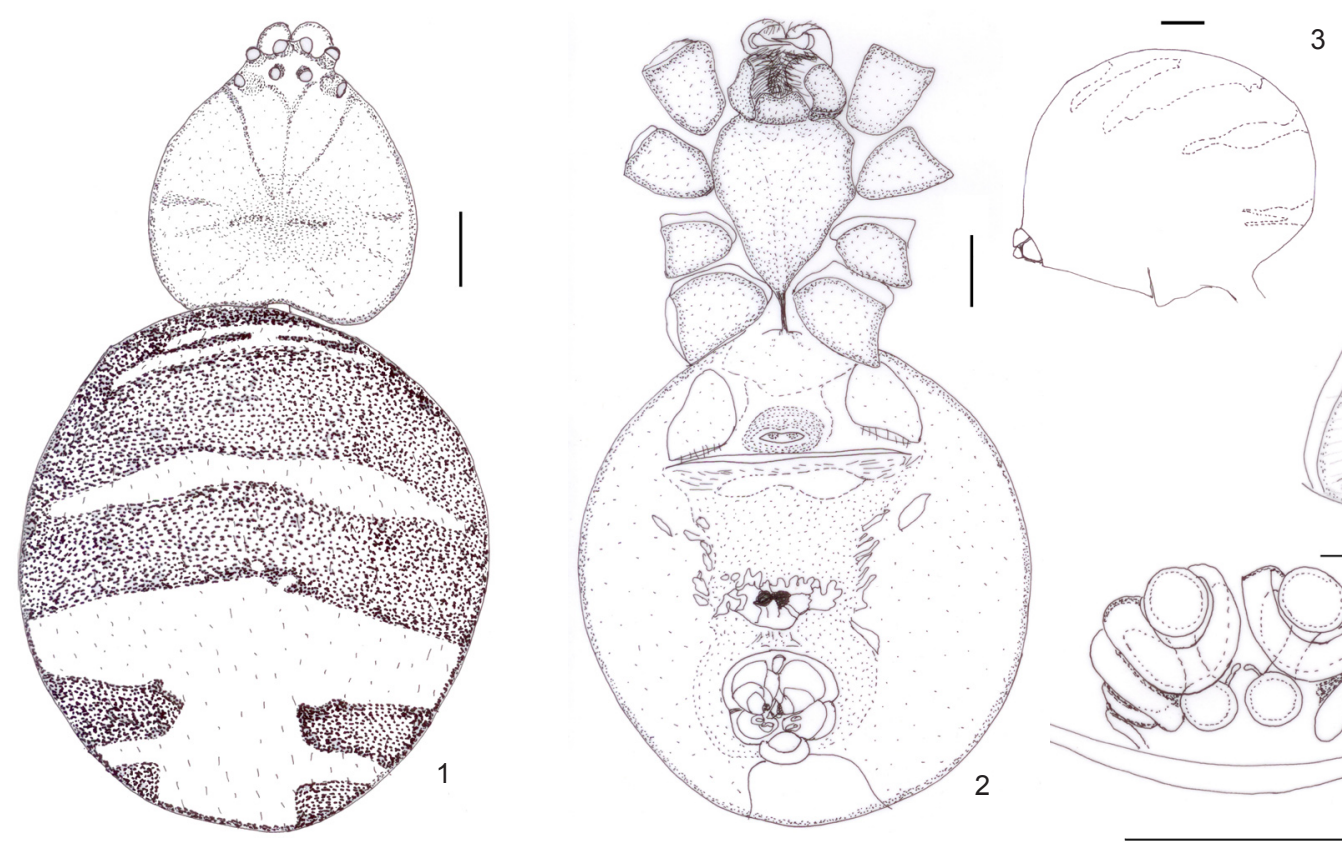

3

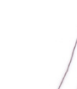

4

Figures 1-5. Latrodectus elegans, female from Manipur (WILD-11-ARA-1113)

1 - Carapace and abdomen dorsal view; 2 - Carapace and abdomen ventral view; 3 - Abdomen, lateral view; 4 - Epigynum, ventral view; 5 - Epigynum, dorsal view. Scale $1.0 \mathrm{~mm}$. 
1
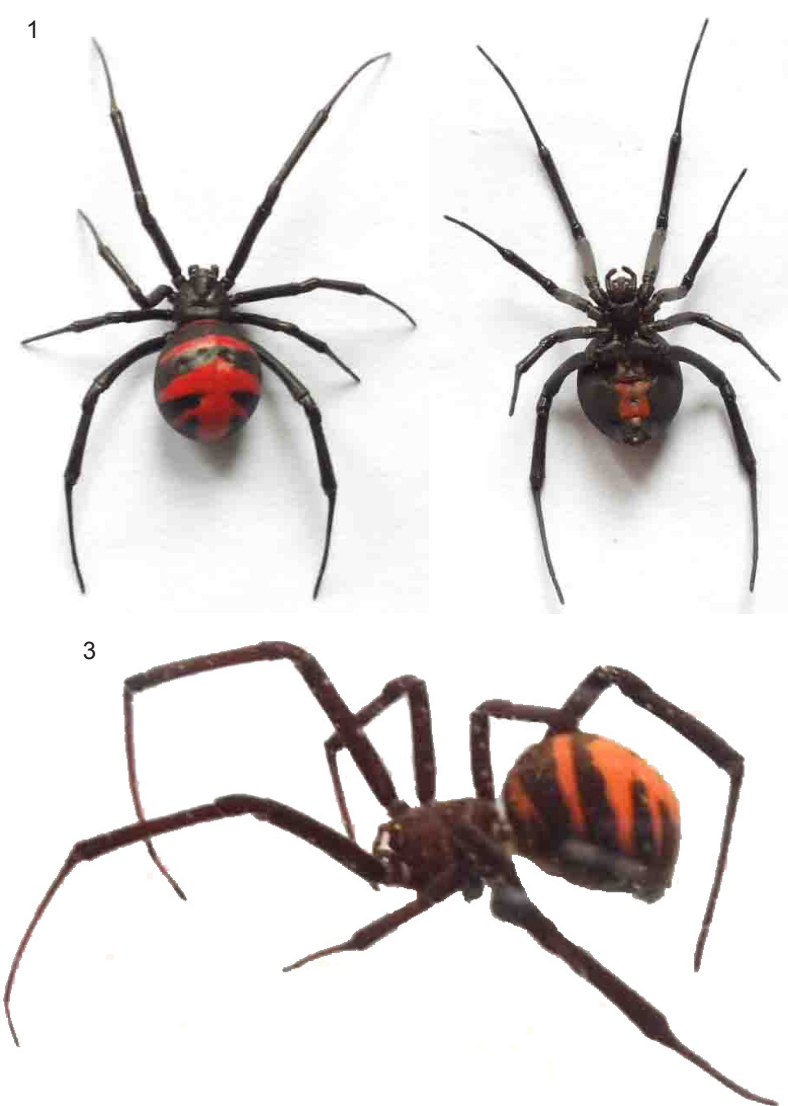

4

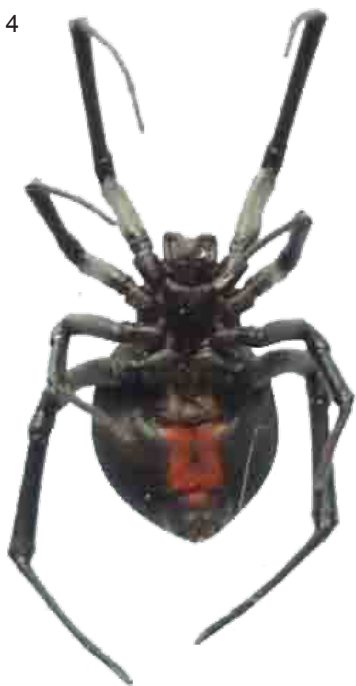

Images 1-5. Latrodectus elegans, female.

1 - Dorsal view; 2 - Ventral view; 3 - Lateral view; 4 - Ventral view; 5 - Epigynum, dorsal view. Images 1-3 of specimen WILD-11-ARA-1113, 4-5 of specimen WILD-11-ARA-1114.

yellowish-orange with 12-15 widely spaced black hair. Leg: formula 1423, coxal base seen from dorsal side, yellowish-orange except distal ends of femora, patella, tibia, metatarsi and tarsi with brown annulets; paired claws without dentitions/teeth, inferior claw present leg I-IV. Palp: yellowish-orange with black annulets
Table 1. Morphometry of legs and palp of female (WILD-11ARA-1113) from Manipur

\begin{tabular}{|l|c|c|c|c|c|}
\hline & Leg I & Leg II & Leg III & Leg IV & Palp \\
\hline Femur & 6.55 & 4.5 & 3.39 & 6.19 & 1.11 \\
\hline Patella & 1.89 & 1.56 & 1,42 & 1.90 & 0.26 \\
\hline Tibia & 4.89 & 3.05 & 2.06 & 4.31 & 0.50 \\
\hline Metatarsi & 6.20 & 3.91 & 3.35 & 5.08 & - \\
\hline Tarsi & 1.94 & 1.50 & 1.17 & 1.70 & 0.95 \\
\hline Total & 21.47 & 14.52 & 9.97 & 19.18 & 2.82 \\
\hline
\end{tabular}

on tarsi, single curve claw without teeth.

Abdomen (Figs. 1-3; Images 1-3): globular, slightly longer than wide, overlapping carapace, covered uniformly with small black hairs. Spinnerets, three pairs, conical, situated towards posterior end (Fig. 2). Colulus large.

Epigynum (Figs. 4-5): Ventrally, opening of epigynum lip shape, anterior lip with a notch in the centre and posterior lip gently curved and not extending on each side beyond opening of epigynum (Fig. 4). Dorsally, seminal receptacles dumbbell-shaped, constriction in the middle; short, curved fertilization duct on the prolateral side of the posterior receptacles; copulatory ducts coiled four times around the seminal receptacles and opens externally; median parts of copulatory ducts loop back near anterior seminal receptacles as seen in L. mactans (Fig. 5).

\section{Remarks}

The ventral red hour-glass marking was very evident and bright in all the spiders in life (Images. $2,4)$. But on preserving them in $70 \%$ alcohol, in one of the specimens, the ventral red hour-glass marking disappeared except for two small patches (Image 2 ), one below epigastral furrow and another above spinnerets, the connecting red patch disappeared. The only difference between Sri Lanka L. erythromelas and Australian Red-back Spider L. hasselti is the absence of hour glass marking on ventral side of abdomen. With the present finding, the ventral abdomen hourglass marking becoming invisible in alcohol raises questions about L. erythromelas as the spider would have been described based on preserved specimens and it is likely that the hour-glass marking disappeared in the preserved specimen. Moreover, Latrodectus shows high variability within the species and also different stages of growth (Levi 1959; Knoflach \& 
van Harten 2002; Garb et al. 2004) therefore, it is also possible that absence of hour-glass marking could be a variable character as observed in some Latrodectus spp. (Knoflach \& van Harten 2002) rather than being a species character (Garb et al. 2004). It needs to be further investigated with the help of molecular techniques carried out on fresh collections from India and Sri Lanka.

\section{Distribution}

China, Myanmar, Japan and present record of the species from Manipur, India.

\section{Natural History}

Manipur gets high rainfall throughout the year, with an annual average rainfall of 1600 to $2100 \mathrm{~mm}$ and temperature varies between -3 to $35{ }^{\circ} \mathrm{C}, 2010$ (Metrological Department, A.A.I., Changangei, Imphal). Dominant vegetation consists of Tectona grandis, Pinus spp., Quercus delbata, some shrubs like Lantana camara and local wild flora.

The habitat from where L. elegans specimens were collected was a moist evergreen forest with red soil. Spiders were found inside holes on roadside bunds near a degraded forest. The hole was covered with tangle web and at the bottom of the web there was a pile of dry leaves and insects exuvia (majority of it was cricket exuvia), which the spider would have eaten. Two egg-sacs were collected along with the spider (WILD-11-ARA-1113) from its web. The diameter of each egg-sac was about $12 \mathrm{~mm}$ and creamish in colour.

The collected egg-sacs were kept in a jar in the lab and monitored. Out of curiosity, one of the egg-sacs was torn after two weeks of collection and about 49 spiderlings emerged from it. None of them survived more than 47 days. Whereas, from the second eggsac, after nearly three weeks of collection, about 180 190 spiderlings emerged. The hourglass mark first started appearing on the spiderlings after 12-13 days, whereas the red mark on the dorsal side of the abdomen appeared after 59 days of emergence from the egg-sac. Moulting was observed in spiderlings three times, after the $14^{\text {th }}, 62^{\text {nd }}$ and $110^{\text {th }}$ day of their emergence from the egg-sac. Only one spiderling survived for 113 days and was later released into the place it was collected from as feeding it live food was a problem.

\section{REFERENCES}

Athreya, R. (2006). A new species of Liocichla (Aves: Timaliidae) from Eaglenest Wildlife Sanctuary, Arunachal Pradesh, India. Indian Birds 2(4): 82-94.

Choudhury, A. (2001). An overview of the status and conservation of the Red Panda Ailurus fulgens in India, with reference to its global status. Oryx 35(3): 250-259.

Corbet, G.B. \& J.E. Hill (1992). The Mammals of The Indomalayan Region: A Systematic Review. Oxford University Press Oxford, 488.

Daniel, J.C. \& P.W. Soman (1961). Observations on the spider Latrodectus hasseltii indicus Simon with a note on arachnidism. Journal of the Bombay Natural History Society 58(3): 823-826.

Datta, A., J. Pansa, M. Madhusudan \& C. Mishra (2003). Discovery of the Leaf Deer Muntiacus putaoensis in Arunachal Pradesh: An addition to the large mammals of India. Current Science 84(3): 454-458.

Devi, L.S. \& P. Yadava (2006). Floristic diversity assessment and vegetation analysis of tropical semievergreen forest of Manipur, north east India. Tropical Ecology 47(1): 89-98.

Garb, J.E., A. Gonzalez \& R.G. Gillespie (2004). The Black Widow Spider genus Latrodectus (Araneae: Theridiidae): phylogeny, biogeography, and invasion history. Molecular phylogenetics and evolution 31(3): 1127-1142.

Hora, S.L. (1944). On the Malayan Affinities of the freshwater fish fauna of peninsular India, and its bearing on the probable age of the Garo-Rahmahal Gap. Proceedings of National Institute of Science, India 10(4): 423-439.

Javed, S., C. Srinivasulu \& F. Tampal (2010). Addition to araneofauna of Andhra Pradesh, India: occurrence of three species of Argyrodes Simon, 1864 (Araneae: Theridiidae). Journal of Threatened Taxa 2(6): 980-985.

Knoflach, B. \& A. van Harten (2002). The genus Latrodectus (Araneae: Theridiidae) from mainland Yemen, the Socotra Archipelago and adjacent countries. Fauna of Arabia 19: 321-362.

Koopman, K.F. (1989). Distributional patterns of IndoMalayan bats (Mammalia, Chiroptera). American Museum Novitates (2942): 17-19.

Kumar, M.G. \& M. Siliwal (2005). Range extension of Latrodectus hasselti Thorell, 1870 (Araneae: Theridiidae). Zoos' Print Journal 20(11): 2072.

Levi, H.W. (1959). The spider genus Latrodectus (Araneae, Theridiidae). Transactions of the American Microscopical Society 78(1): 7-43.

Mahony, S. (2009). A new species of gecko of the genus Hemidactylus (Reptilia: Gekkonidae) from Andhra Pradesh, India. Russian Journal of Herpetology 16(1): 27-34.

Mahony, S. \& G.R. Zug (2008). Hemidactylus karenorum (Squamata, Gekkonidae) in India. Hamadryad 32(1): 8486.

Ningombam, B. \& S. Bordoloi (2007). Amphibian fauna of Loktak Lake, Manipur, India with ten new records for the State. Zoos' Print Journal 22(5): 2688-2690. 
Platnick, N.I. (2012). The World Spider Catalog. version 12.5 . American Museum of Natural History, online at http:// research.amnh.org/iz/spiders/catalog. Downloaded on 2 January 2012.

Pocock, R.I. (1900). The Fauna of British India, Including Ceylon and Burma - Arachnida. Taylor and Francis, London, 273pp.

Shukla, S. \& V. Broome (2007). First report of the Brown Widow Spider, Latrodectus geometricus CL Koch (Araneae: Theridiidae) from India. Current Science 93(6): 775-777.
Siliwal, M. \& D. Kumar (2001). Rare sighting of poisonous spider Latrodectus hasseltii indicus Simon (Araneae: Theridiidae) in a cotton field in Baroda District, Gujarat. Current Science 81(9): 1170.

Simon, E. (1897). Arachnides recueillis par M. M. Maindron à Mascate, en octobre 1896. Bulletin du Museum (national) d'histoire naturelle, Paris: 95-98pp.

Slowinski, J.B., S.S. Pawar, H. Win, T. Thin, S. Gyi, S. Oo \& H. Tun (2001). A new Lycodon (Serpentes: Colubridae) from Northeast India and Myanmar (Burma). Proceedings of California Academy of Sciences 52(20): 397-405. 